\title{
STRUKTUR KOMUNITAS TERIPANG DI PERAIRAN DESA TANOMEHA KABUPATEN WAKATOBI
}

\section{Community structure of sea cucumbers Tanomeha waters, Wakatobi Regency}

\author{
Darmisa $^{1}$, Emiyarti $^{2}$, dan La Ode Alirman $\mathrm{Afu}^{3}$ \\ ${ }^{1}$ Mahasiswa Jurusan Ilmu Kelautan, \\ Fakultas Perikanan dan Ilmu Kelautan, Universitas Halu Oleo. \\ Jl. H.E.A Mokodompit Kampus Hijau Bumi Tridharma Anduonohu Kendari 93232, Telp/Fax: (0401) 3193782 \\ ${ }^{2}$ Surel: emiyarti@ymail.com \\ ${ }^{3}$ Surel: alirmanotsudari@yahoo.co.id
}

\begin{abstract}
Abstrak
Teripang merupakan salah satu sumberdaya hayati laut ekonomis penting dan mempunyai peluang pasar cukup baik. Tujuan dari penelitian ini untuk mengetahui sturktur komunitas teripang meliputi kepadatan, keanekaragaman, keseragaman dan dominansi. Penelitian ini di lakukan di Perairan Desa Tanomeha Kecamatan Kaledupa Selatan Kabupaten Wakatobi pada bulan Januari-Maret 2019. Metode yang digunakan dalam penelitian ini adalah transek kudrat, dibagi menjadi 3 stasiun. Hasil pengamatan menunjukkan bahwa terdapat 10 spesies teripang yang di klasifikasikan dalam 3 genus (Holothuria, Bohadschia dan Stichopus). Berdasarkan perhitungan struktur komunitas menunjukkan kepadatan teripang tertinggi untuk kedua fase bulan yakni pada bulan terang $0,195 \mathrm{ind} / \mathrm{m}^{2}$ ditemukan di daerah lamun yang bersubtrat pasir berlempung. Untuk kenaekaragaman nilai tertinggi diperoleh pada bulan terang sebesar 1,58 dan bulan gelap 0,34 . Sedangkan nilai keseragaman jenis yang paling tinggi diperoleh pada bulan terang di daerah lamun berkisar 1,79 dan bulan gelap berkisar 1,60. Dominansi nilai paling tinggi diperoleh pada bulan terang sebesar 0,78 dan bulan gelap sebesar 0,80 yang keduanya berada pada daerah mangrove. Parameter kualitas perairan yang diukur dalam lokasi penelitian memiliki kondisi lingkungan yang baik untuk kehidupan teripang.
\end{abstract}

Kata Kunci: Sturktur komunitas, Teripang, Perairan Tanomeha

\begin{abstract}
Sea Cucumber are one of the essential economic of marine resources that have a reasonably good market opportunity. This study aims to determine the community structure of the sea cucumber, i.e., density, diversity, uniformity, and dominance. The study was located in the Tanomeha village Waters, South Kaledupa Subdistrict, Wakatobi District from January to march 2019. The data was collected by using quadrat transect, which was divided into there stations. The result showed that ten species of sea cucumbers classified in there genera (e.g., Holothuria, Bohadschia and Stichopus). Based on the calculation, the density of sea cucumbers occurred in the bright moon of $0.195 \mathrm{ind} . / \mathrm{m}^{2}$ in seagrass areas with very fine sand substrate. For diversty, the highest value obtained in the bright moon is 1.58 , and the dark moon is 0.34 . Whereas the highest value of species uniformity was obtained in the bright moon in the seagrass area at 1.79 and the dark moon at 1.60. The highest value of dominance was obtained both bright months at 0.78 and the dark moon at 0.80 , which are both in the mangrove area. The water quality parameters measured in the study site have a good environmental condition for the life of sea cucumber.
\end{abstract}

Key words: Community structure, sea cucumber, Tanomeha waters

\section{Pendahuluan}

Teripang merupakan salah satu sumber daya hayati laut ekonomis penting dan mempunyai peluang pasar cukup baik.Teripang dapat dijumpai tidak hanya di perairan dangkal, namun ada juga yang hidup di laut dalam, bahkan di palung laut yang terdalam. Habitat teripang berupa ekosistem lamun dan ekosistem terumbu karang, mulai dari zona intertidal sampai kedalaman 20 meter.

Jenis teripang yang ditemukan di Indonesia sebanyak $50 \%$ dan 650 jenis yang ada di dunia (Samad, 2000). Diketahui bahwa sekitar 25 jenis teripang berpotensi komersial diidentifikasi berasal dari perairan Indonesia. Daerah penghasil teripang terbesar adalah pantai-pantai di Indonesia Timur. Darsono (2005) melaporkan bahwa terjadi penurunan populasi di tempat-tempat penghasil teripang di Indonesia. Demi ketersediaan spesiesspesies komersial untuk memenuhi permintaan pasar sehingga tidak mengandalkan teripang yang diambil langsung dari habitatnya, beberapa jenis sudah dibudidayakan antara lain di Lampung, Sulawesi Selatan, Sulawesi Tenggara, dan Lombok.

Perairan Tanomeha terletak di Kecamatan Kaledupa Selatan Kabupaten 
Wakatobi. Perairan ini memiliki potensi sumber daya alam berupa terumbu karang, lamun dan mangrove dengan dasar berupa pasir dan lumpur. Secara langsung maupun tidak langsung teripang-teripang ini memanfaatkan terumbu karang dan lamun dengan dasar berupa pasir berlempung dan pasir sebagai tempat tinggal dan sumber makanan melalui rantai makanan.

Organisme laut seperti teripang, kehidupannya dipengaruhi oleh kondisi lingkungan tepat di mana teripang itu hidup, seperti sedimen, suhu, salinitas dan arus disebabkan pada masing-masing bagian perairan laut, memiliki karakteristik lingkungan yang berbeda.Perbedaan tersebut mengakibatkan perbedaan kepadatan teripang pada suatu daerah yang lainnya.

Struktur komunitas perlu di teliti karena belum adanya informasi awal mengenai struktur komunitas teripang di Perairan Desa Tanomeha. Sampai saat ini belum diketahui bagaimana struktur komunitas teripang yang ada di Perairan Desa Tanomeha ini sehingga sangat perlu diadakan penelitian untuk mengetahui bagaimana struktur komunitas teripang dengan menyajikan data berupa kepadatan, keanekaragaman, dominansi dan keseragaman jenis dari teripang di Perairan Tanomeha. Ada peneliti yang mengkaji tentang sturktur komunitas sedangkan di perairan desa Tanomeha Kecamatan Kaledupa Selatan Kabupaten Wakatobi belum ada yang mengkaji tentang hal tersebut.

Tujuan penelitian ini adalah untuk mengetahui struktur komunitas teripang di
Perairan Desa Tanomeha Kabupaten Wakatobi. Manfaat dari penelitian ini adalah agar dapat memberikan informasi dan data tentang struktur komunitas teripang, dengan dilakukannya penelitian ini informasi dan data yang telah diperoleh dapat dijadikan sebagai sumber tentang struktur komunitas di Perairan Desa Tanomeha untuk pemerintah, masyarakat, insitu, dan penelitian selanjutnya.

\section{Bahan dan Metode}

Penelitian ini dilaksanakan pada bulan Januari-Februari 2019 di Perairan Desa Tanomeha, Kecamatan Kaledupa Selatan, Kabupaten Wakatobi Sulawesi Tenggara.

Prosedur penelitian meliputi survey pendahuluan, penentuan stasiun penelitian, pengambilan data Teripang, pengukuran kualitas air dan pengambilan sampel sedimen. Beberapa parameter fisika perairan yang diukur antara lain, suhu, Kecepatan arus, kecerahan, kedalaman perairan dan tekstur substrat. Pengukuran parameter kimia perairan meliputi bahan organik sedimen, salinitas, $\mathrm{pH}$.

Tahap survey pendahuluan dilakukan untuk mengetahui keberadaan teripang dan melihat kondisi lapangan. Survey ini dilakukan dengan menggunakan alat snorkeling. Berdasarkan survey pendahuluan yang telah dilakukan, lokasi stasiun penelitian menggunakan porposive sampling. Penentuan 3 stasiun penelitian yang dipilih dengan alasan dapat mewakili perairan Desa Tanomeha.

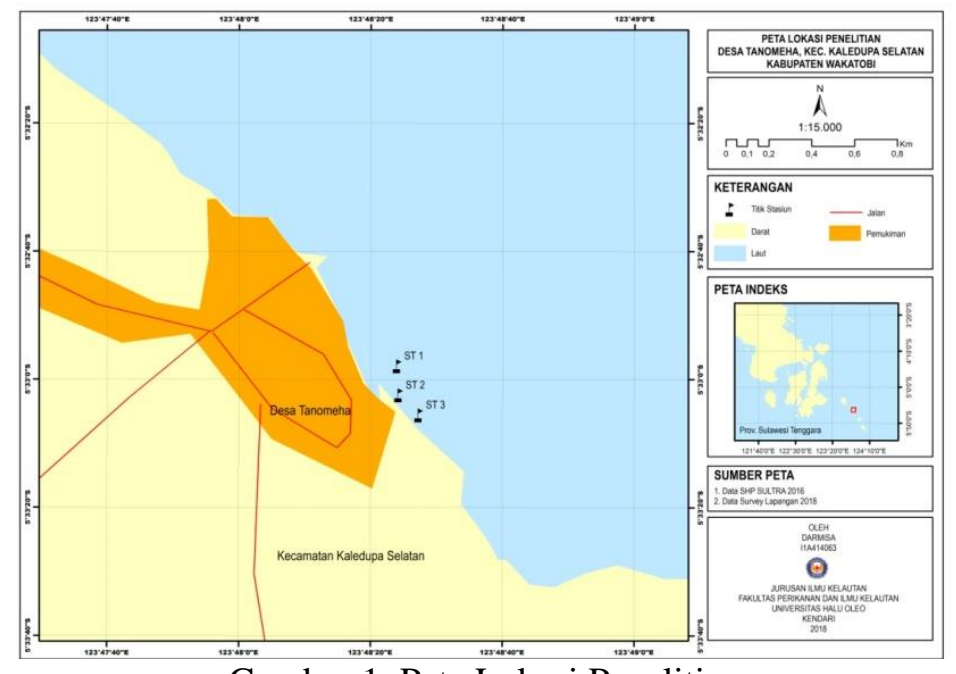

Gambar 1. Peta Lokasi Penelitian 


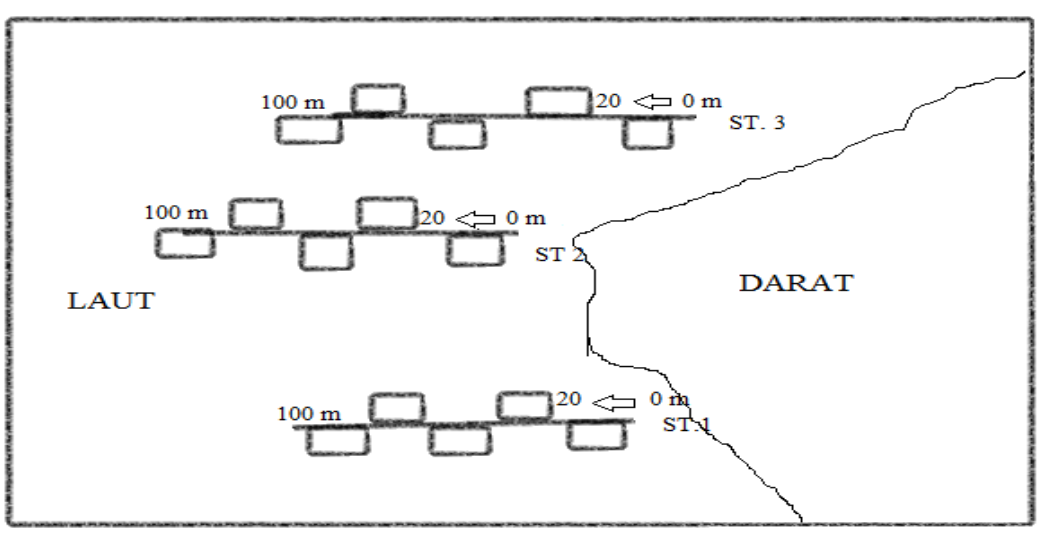

Gambar 2. Sketsa Pengambilan Data Teripang

Lokasi penelitian di Perairan Desa Tanomeha dibagi menjadi 3 stasiun meliputi: Stasiun I, terletak di bagian Selatan Desa Tanomeha, berada pada titik koordinat


ini berada pada daerah mangrove. Stasiun II, terletak di bagian Selatan Desa Tanomeha, berada pada titik koordinat $\left(5^{0} 33^{\prime} 2,49^{\prime \prime}\right.$ LS $123^{\circ} 47^{\prime} 24,23^{\prime \prime}$ BT). Stasiun berada di daerah lamun. Stasiun III, terletak di bagian Selatan Desa Tanomeha, stasiun berada pada titik koordinat $\left(5^{\circ} 33^{\prime} 5,60^{\prime \prime}\right.$ LS - 1234' $27,29^{\prime \prime}$ BT). Stasiun tersebut berada di daerah karang.

Pengambilan data teripang dilakukan pada malam hari dengan dua kali ulangan yakni pada bulan terang dan pada bulan gelap. Transek garis ditarik tegak lurus pantai ke arah laut sepanjang $100 \mathrm{~m}$ pada saat air laut surut atau menjelang surut terendah, mulai dari titik nol diletakkan transek kuadrat $1 \times 1 \mathrm{~m}^{2}$ dengan jarak antar transek $20 \mathrm{~m}$. Sepanjang tali transek yang dianggap dapat mewakili lokasi yang terdapat Tesripang. Teripang di dalam transek kuadrat diamati jenisnya, dihitung jumlah individu dari masing-masing jenis, sedangkan yang belum diidentifikasi dimasukkan ke dalam kantung plastik atau ember dengan menggunakan tangan dan diberi label, dengan menggunakan kertas label. Adapun sketsa pengambilan data dapat dilihat pada Gambar 2.

Pengukuran kualitas perairan dilakukan secara insitu yang bertujuan untuk mengetahui kondisi perairan habitat teripang yang meliputi pengukuran suhu, salinitas, kecepatan arus, $\mathrm{pH}$, kecerahan, kedalaman perairan dan uji tekstur substrat dilakukan di laboratorium.

\section{Analisis Data}

Berdasarkan data kondisi lingkungan perairan dan keanekaragaman, kepadatan teripang. Data yang diperoleh dianalisis secara deskriptif kuantitatif yaitu memberikan gambaran dalam bentuk grafik yang dimaksud agar lebih mudah dibaca atau diinterprestasikan untuk mengetahui kepadatan teripang, indeks keanekaragaman, indeks keseragaman, indeks dominansi. Penyajian data menggunakan Microsoft Excel dalam tabel.

1. Indeks Keanekaragaman

Indeks keanekaragaman jenis (Species Deversity Indeks) (H') digunakan rumus Shannon-Weiner (Odum, 1993) dengan persaman berikut:

$\mathrm{H}^{\prime}=-\Sigma \mathrm{Pi}$ In Pi

Dimana :

$\mathrm{H}^{\prime}$ = Indeks Keanekaragaman

$\mathrm{Pi}=$ Perbandingan total antara jumlah individu jenis ke-i dengan jumlah total individu

$\mathrm{ni}=$ Jumlah individu jenis ke-i

$\mathrm{N}=$ Jumlah total individu

2. Kepadatan Teripang

Kepadatan jenis adalah jumlah individu per satuan luas. Kepadatan masingmasing jenis pada setiap titik koordinat dihitung dengan menggunakan persamaan berikut (Odum,1993).

$\mathrm{Di}=\frac{n i}{A}$

Dimana :

$\mathrm{Di}=$ kepadatan jenis (ind./ $\mathrm{m}^{2}$ )

$\mathrm{ni}=$ jumlah total individu jenis (ind.)

$A=$ luas area yang di sampling $\left(\mathrm{m}^{2}\right)$

3. Indeks Keseragaman Jenis

Indeks keseragaman dapat dikatakan sebagai keseimbangan, yaitu komposisi individu tiap jenis yang terdapat dalam suatu 
komunitas. Indeks keseragaman jenis yaitu dengan menggunakan persamaan berikut (Odum, 1993).

$\mathrm{E}=\frac{\mathrm{H} \prime}{\mathrm{H} \text { maks }}$

Dimana :

$\mathrm{E}=$ Indeks Keseragaman

$\mathrm{H}=$ Indeks keanekaragaman jenis

$\mathrm{H}$ maks = Jumlah jenis organisme $(\ln \mathrm{S})$

4. Indeks Dominansi

Indeks dominansi dihitung dengan menggunakan persamaan berikut (Odum, 1993).

$\mathrm{D}=\sum(\mathrm{ni} / \mathrm{N})^{2}$

Dimana :

$\mathrm{D}=$ Indeks Dominansi

ni $=$ Jumlah individu spesies ke-i

$\mathrm{N}=$ Jumlah total individu setiap jenis

\section{Hasil dan Pembahasan}

Kepadatan teripang tertinggi untuk kedua fase bulan ditemukan pada Stasiun II dan dan terendah pada Stasiun I. Pada fase bulan terang kepadatan tinggi yang ditemukan yakni $0,195 \mathrm{ind} / \mathrm{m}^{2}$ dan kepadatan rendah yakni $0,075 \mathrm{ind} / \mathrm{m}^{2}$. Sedangkan pada fase bulan gelap kepadatan teripang tinggi yang ditemukan adalah $0,37 \mathrm{ind} / \mathrm{m}^{2}$ dan rendah yakni $0,19 \mathrm{ind} / \mathrm{m}^{2}$. Teripang jenis $B$. similis memiliki kepadatan tertinggi di tiap fase bulan, tingginya kepadatan teripang pada Stasiun II diduga karena adanya nilai suhu yang diperoleh selama penelitian yaitu pada bulan terang dan gelap sesuai dengan kehidupan teripang dimana nilai suhu sebesar $27-28^{\circ} \mathrm{C}$, sesuainya nilai suhu yang diperoleh selama bulan penelitian secara tidak langsung dapat mempengaruhi keberadaan, kelangsungan hidup dan fungsi biologis teripang tersebut seperti reproduksi.

Nilai suhu perairan yang diperoleh selama penelitian menunjukan frekuensi yang tidak terlalu besar. Hal ini disebabkan oleh kondisi cuaca pada malam hari cukup tenang. Kondisi ini menunjukan bahwa nilai kisaran suhu tersebut dapat ditolelir teripang. Menurut pernyataan (Herman, 2016) bahwa suhu berperan mengatur kehidupan biota perairan, kenaikan suhu dapat menyebapkan peningkatan komsumsi oksigen bagi organisme, namun di sisi lain mengakibatkan turunnya kelarutan oksigen dalam air, suhu memberikan pengaruh besar terhadap kehidupan teripang terutama untuk proses reproduksi dan pertumbuhan. Suhu yang ditemukan selama waktu penelitian berkisar $26-28^{\circ} \mathrm{C}$, kisaran suhu ini masih dalam batas toleransi teripang dan kisaran suhu yang baik untuk pertumbuhan dan tahap perkembangan gonad teripang.

Kepadatan teripang terendah untuk kedua fase bulan ditemukan pada Stasiun I. Pada fase bulan terang kepadatan yang ditemukan yakni $8 \mathrm{ind} / \mathrm{m}^{2}$ dan pada fase bulan gelap kepadatan teripang yang ditemukan berkisar antara $18 \mathrm{ind} / \mathrm{m}^{2}$. Berdasarkan hasil penelitian teripang jenis $H$. impatians memiliki kepadatan terendah di tiap fase bulan. Rendahnya kepadatan teripang pada Stasiun I diduga karena pada bulan terang dan gelap kandungan bahan organiknya tinggi sehingga menyebabkan pembusukan bahan organik dalam perairan. Selain itu, biota yang hidup pada subtrat tersebut juga akan sangat sulit mendapatkan oksigen yang baik karena partikel subtrat yang begitu kecil.

Menurut pernyataan (Nybakken, 1992) bahwa pada perairan dengan subtrat lumpur umumnya banyak terdapat bentos pemakan deposit (deposit feeder), teripang yang bersifat sebagai deposit feeder yang terdapat pada tipe subtrat ini umumnya akan kesulitan karena partikek-partikel lumpur akan menyumbat saluran respirasi teripang. Hal ini disebabkan tingginya bahan organik pada Stasiun I dengan nilai berkisar 2,00-2,08\%, sehingga suplai makanan untuk kehidupan teripang kurang. Selain itu, teripang tidak menyukai subtrar yang berlumpur. Teripang adalah pemakan deposit pasir, sedangkan sumber makanannya diantaranya organisme kecil, detritus, partikelpartikel pasir ataupun hancuran karang dan cangkang hewan lainnya.

Stasiun II dan III keanekaragaman sedang karena pada fase bulan terang dan gelap sumber makanan melimpah serta kondisi subtrat dan suhu yang mendukung pertumbuhan teripang serta berkembang biak secara cepat. Hal ini sesuai pernyataan (Narayaman, 2014) bahwa suhu adalah faktor penentu bagi pemijahan teripang, ketika suhu $27^{\circ} \mathrm{C}$ perilaku teripang terlihat sangat aktif, kemudian dengan selang waktu \pm 30 suhu dinaikkan menjadi 28 teripang melakukan proses pemanjangan tubuh dan merupakan fase persiapan pemijahan. Setelah suhu dinaikkan menjadi $29^{\circ} \mathrm{C}$, teripang melakukan pemijahan yang sempurna, teripang jantan melepaskan sperma dan setelah selang waktu 10 menit teripang betina melepaskan sel telur. 
Tabel 1. Jenis teripang yang ditemukan

\begin{tabular}{|c|c|c|c|c|}
\hline \multirow{2}{*}{ Waktu } & \multirow{2}{*}{ Jenis } & \multicolumn{3}{|c|}{ Stasiun } \\
\hline & & I & II & III \\
\hline \multirow[t]{10}{*}{ Bulan Terang } & Holothuria atra & $\sqrt{ }$ & $\sqrt{ }$ & $\sqrt{ }$ \\
\hline & Holothuruia edulis & & & $\sqrt{ }$ \\
\hline & Holothuria turriscelsa & & & $\sqrt{ }$ \\
\hline & Stichopus variegates & & & $\sqrt{ }$ \\
\hline & Bohadchia similis & & $\sqrt{ }$ & \\
\hline & Holothuria scabra & & $\sqrt{ }$ & $\sqrt{ }$ \\
\hline & Holothuria thymiosycia & & $\sqrt{ }$ & \\
\hline & Holothuria impatiens & $\sqrt{ }$ & & \\
\hline & Holothuria coluber & & $\sqrt{ }$ & \\
\hline & Holothuria argus & & $\sqrt{ }$ & \\
\hline \multirow[t]{9}{*}{ Bulan Gelap } & Holothuria atra & $\sqrt{ }$ & $\sqrt{ }$ & $\sqrt{ }$ \\
\hline & Holothuruia edulis & & & $\sqrt{ }$ \\
\hline & Holothuria turriscelsa & & & $\sqrt{ }$ \\
\hline & Stichopus variegates & & & $\sqrt{ }$ \\
\hline & Bohadchia similis & & $\sqrt{ }$ & \\
\hline & Holothuria scabra & & $\sqrt{ }$ & $\sqrt{ }$ \\
\hline & Holothuria impatiens & $\sqrt{ }$ & & \\
\hline & Holothuria coluber & & $\sqrt{ }$ & \\
\hline & Holothuria argus & & $\sqrt{ }$ & \\
\hline
\end{tabular}

Tabel 2. Kepadatan teripang pada bulan terang dan gelap selama penelitian

\begin{tabular}{ccc}
\hline \multirow{2}{*}{ Stasiun } & \multicolumn{2}{c}{ Kepadatan $\left(\mathbf{I n d} / \mathbf{m}^{2}\right)$} \\
\cline { 2 - 3 } & Bulan terang & Bulan gelap \\
\hline I & 0,075 & 0,19 \\
II & 0,195 & 0,37 \\
III & 0,135 & 0,27 \\
\hline
\end{tabular}

Tabel 3. Keanekaragaman, keseragaman dan dominansi teripang

\begin{tabular}{cccc}
\hline Stasiun & Keanekaragaman $(\mathbf{H})$ & Keseragaman $(\mathbf{E})$ & Dominansi $(\mathbf{D})$ \\
\hline I & 0,37 (Rendah) & 0,69 (Sedang) & 0,80 (Tinggi) \\
II & 1,47 (Sedang) & 1,79 (Tinggi) & 0,31 (Rendah) \\
III & 1,58 (Sedang) & 1,60 (Tinggi) & 0,25 (Rendah) \\
\hline
\end{tabular}

Keanekaragaman teripang terendah di temukan pada Stasiun I yakni 0,37 (rendah). Rendahnya nilai keanekaragaman teripang pada Stasiun I dipengaruhi oleh habitat hidup sebagai ketersediaan makanan yang tidak cukup serta cuaca yang sewaktuwaktu tidak cocok untuk teripang. Hal ini sesuai pernyataan (De Beer, 1990) bahwa distribusi dan perkembangan teripang sangat tergantung pada subtrat, jumlah jenis makanan yang tersedia diperaiaran tersebut.

Hasil dari tekstur subtrat menunjukan bahwa pada Stasiun I bersubtrat lumpur bepasir, Stasiun II pasir berlempung dan Stasiun III pasir. Tipe subtrat yang disukai teripang jenis $B$. similis dan $H$. argus terdapat pada tipe subtrat pasir berlempung, dan pada tipe subtrat lumpur berpasir disukai oleh teripang jenis $H$. atra. Jenis teripang seperti $H$. edulis, $H$. turriscelsa, dan S. variegatus menyukai tipe subtrat pasir pada daerah karang. $H$. coluber, $H$. argus dan $H$. thymiosycia menyukai tipe subtrat pasir berlempung pada daerah lamun.

Keanekaragaman jenis teripang yang diperoleh selama penelitian pada bulan terang dan bulan gelap terdiri dari sepuluh jenis teripang yaitu $H$. atra, $H$. edulis, $H$. turriscelsa, S. variegatus, $B$. similis, $H$. scabra, $H$. thymiosycia, $H$.impatians, $H$. coluber, dan $H$. argus yang ditemukan pada setiap Stasiun dengan jumlah bervariasi. 
Tabel 4. Hasil analisis parameter kualitas perairan

\begin{tabular}{|c|c|c|c|c|}
\hline \multirow{2}{*}{ No } & \multirow{2}{*}{$\begin{array}{l}\text { Parameter } \\
\text { kualitas air }\end{array}$} & \multirow{2}{*}{ Stasiun } & \multicolumn{2}{|c|}{ Waktu penelitian } \\
\hline & & & Bulan terang & Bulan gelap \\
\hline \multirow[t]{3}{*}{1} & Suhu $\left({ }^{\circ} \mathrm{C}\right)$ & I & 27 & 28 \\
\hline & & II & 28 & 28 \\
\hline & & III & 27 & 27 \\
\hline \multirow{3}{*}{2} & Kecepatan Arus & I & 0,28 & 0,24 \\
\hline & & II & 0,33 & 0,31 \\
\hline & & III & 0,36 & 0,34 \\
\hline \multirow[t]{3}{*}{3} & $\mathrm{Ph}$ & I & 7 & 7 \\
\hline & & II & 7 & 7 \\
\hline & & III & 7 & 7 \\
\hline \multirow[t]{3}{*}{4} & Salinitas (ppt) & $\mathrm{I}$ & 29 & 28 \\
\hline & & II & 28 & 29 \\
\hline & & III & 30 & 28,5 \\
\hline \multirow[t]{3}{*}{5} & Kedalaman (m) & I & $0,5-1$ & $1-2$ \\
\hline & & II & $1-2$ & $1-4$ \\
\hline & & III & $1-3$ & $1-5$ \\
\hline \multirow[t]{3}{*}{6} & Substrat & I & Lumpur berpasir & Lumpur berpasir \\
\hline & & II & Pasir berlempung & Pasir berlempung \\
\hline & & III & Pasir & Pasir \\
\hline \multirow[t]{3}{*}{7} & $\mathrm{BO}(\%)$ & I & 2,08 & 2,00 \\
\hline & & II & 1,33 & 1,42 \\
\hline & & III & 0,48 & 0,56 \\
\hline
\end{tabular}

Keseragaman yang ditemukan meliputi Stasiun I dengan nilai sebesar 0,69, Stasiun II dengan nilai sebesar 1,79 dan Stasiun III dengan nilai sebesar 1,60. Keseragaman teripang yang didapatkan di perairan Desa Tanomeha yang tinggi yaitu pada Stasiun II dan III berkisar antara 1,60-1,79 (tinggi). Keseragaman teripang tinggi bahwa selisih antara jumlah jenis lebih seragam yang mencirikan bahwa keadaan perairan dalam kondisi yang masih baik bagi kehidupan teripang. Pengaruh salinitas selama periode penelitian tetap konstan berkisar antara 28-30 ppt, nilai salinitas yang diperoleh masih mendukung kelangsungan hidup teripang. Hal ini sesuai dengan pernyataan (Aziz, 1997) bahwa umumnya teripang menyukai perairan dengan kisaran salinitas normal sekitar 30-34 ppt. Menurut Wati (2005) jika indeks keseragaman lebih dari 0,6 maka ekosistem tersebut dalam kondisi stabil dan mempunyai keseragaman tinggi.
Hasil keseragaman yang didapatkan di perairan Desa Tanomeha yang rendah yaitu pada Stasiun I berkisar antara 0,69 (sedang). Keseragaman teripang terendah disebabkan faktor lingkungan yang ekosistemnya berada dalam kondisi tertekan dan mempunyai keseragaman rendah. Hal ini sesuai dengan pernyataan (Wati, 2013) bahwa jika indeks keseragaman antara 0,4-0,6 maka ekosistem tersebut berada pada kondisi kurang stabil dan mempunyai keseragaman sedang. Jika indeks keseragaman lebih dari 0,6 maka ekosistem tersebut berada pada kondisi stabil dan mempunyai keseragaman tinggi.

Hasil pengamatan yang diperoleh selama penelitian pada setiap bulan pengamatan yaitu bulan terang dan bulan gelap memperlihatkan jenis teripang yang mendominansi yaitu teripang $H$. atra. Hal ini dikarenakan teripang $H$. atra merupakan jenis yang beraktifitas mencari makan sepanjang hari baik pada malam maupun siang hari. Hal ini sesuai dengan pernyataan 
(Pawson, 1970), yang menyatakan bahwa berdasarkan aktivitas hariannya pada teripang H. atra maka dapat digolongkan kedalam tiga kelompok yaitu aktivitas makan sepanjang hari, makan pada malam hari, selain itu juga teripang $H$. atra juga mempunyai kemampuan beradaptasi yang tinggi baik terhadap faktor biologi dan fisik.

Hasil analisis dominansi teripang di Perairan Desa Tanomeha Kecamatan Kaledupa Selatan, menunjukan bahwa berkisar antara 0,80 (Tinggi) yang terdapat pada Stasiun I. Hal ini menunjukan bahwa dari hasil analisis dominansi teripang memperlihatkan bahwa di perairan tersebut terdapat spesies yang dominan. Berdasarkan kategori (Odum, 1993), nilai dominansi yang didapatkan tergolong tinggi dan masih stabil karena karena nilai yang diperoleh lebih dari 0,75 . Berdasarkan nilai indeks dominansi pada bulan terang stasiun I diketahui bahwa tidak terdapat nilai yang ekstrim mendominansi spesies lainnya. Hal ini disebabkan oleh kondisi cuaca pada malam hari selama penelitian tidak jauh berbeda, kondisi ini menunjukukan bahwa kisaran suhu tersebut dapat ditolerir oleh teripang.

Hasil analisis dominansi teripang di Perairan Desa Tanomeha Kecamatan Kaledupa Selatan, menunjukan bahwa dominansi terendah terdapat pada Stasiun II dan III berkisar antara 0,25-0,31 (rendah). Hal ini menunjukan bahwa dari hasil analisis dominansi teripang terendah pada fase bulan terang dan gelap memperlihatkan bahwa tidak ada jenis yang dominan menguasai jumlah teripang.Wati (2005), menambahkan bahwa apabila indeks dominansi $>0,5$ maka struktur komunitas yang diamati ada dominansi dari satu atau beberapa spesies.

\section{Simpulan}

Berdasarkan hasil penelitian yang telah dilakukan di Perairan Desa Tanomeha dapat disimpulkan bahwa teripang yang di dapat yakni H.atra, H.edulis, H.turriscelsa, Stichopus variegatus, Bohadschia similis, H.scabra, H.thymiosycia, H.impatians, H.coluber, dan H.argus.

Kepadatan teripang tertinggi untuk kedua fase bulan ditemukan yakni bulan terang $0,195 \mathrm{ind} / \mathrm{m}^{2}$ pada daerah lamun bersubstrat pasir berlempung. Keanekaragaman nilai yang paling tinggi diperoleh yakni bulan terang 1,58 dan pada bulan gelap 0,34. Keseragaman jenis nilai yang paling tinggi diperoleh pada bulan terang pada daerah lamun berkisar 1,79 dan bulan gelap berkisar 1,60. Dominansi nilai yang paling tinggi diperoleh pada bulan terang sebesar 0,78 dan bulan gelap sebesar 0,80 keduanya terdapat pada daerah mangrove.

\section{Daftar Pustaka}

Aziz, A. 1997. Status Penelitian Teri-pang Komersial di Indonesia. Balitbang Biologi Laut, Puslitbang OseanologiLIPI, Jakarta. 9-19 hal.

Bakus GJ. 1973. The Biology and Ecology ofTropical Holothurian, In : O.A. Jonesdan Enoean (Eds.) Biology and Geologyof Coral Reef. Vol 2, Academic Press,New York : 325-357.

Bengen, D.G. 2000. Sinopsis Teknis Pengambilan Contoh dan Analisis DataBiofisik Sumberdaya Pesisir. Bogor: PKSPL IPB.

Canon, L.R.G. and H. Silver 1986. Sea cucumber of Nothern Australia. Queensland Museum, Brisbane : $60 \mathrm{pp}$

Dahuri, R. 2003. Keanekaragaman Hayati Laut. Gramedia Pustaka Utama. Jakarta.

Darsono, P., 1998. Pengenalan Secara Umum tentang Teripang, (Holothuridea). Pusat Penelitian Oseanografi , 1:1-8 hal.

Darsono, P., 2005. Teripang (Holothurians) Perlu Dilindungi, Ikatan Sarjana Oseanologi Indonesia, 9 Maret 2005.

Darsono, P. 2007. Teripang (Holothuroidea): Kekayaan Alam Dalam Keragaman Biota Laut. Oseana, Volume XXXII, Nomor 2. Bidang Sumberdaya Laut, Pusat Penelitian Oseanografi-LIPI, Jakarta. 1-10 hal.

De Beer M. 1990. Distribution Paterns of Reguler Sea Urchin (Echinodermata: Echinodeae) Across the Spermonde Shelf, SW Sulawesi (Indonesia). Proceeding of the Second European Conference on Echinoderm, Brusels/Belgium/18-21 September 1989.

Djunarsjah, E., dan Poerbandono, 2005, Survei Hidrografi. PT. Refika Aditama,Bandung.

Dominggus, R. Gofur, A. Sutomo, H. 1998. Hubungan faktor fisika-kimia lingkungan dengan keanekaragaman 
Echinodermata pada daerah pasang surut Pantai Kairatu. MIPA. 77-85.

Dronkers J.J. 1964. Tidal Computations in Rivers and Coastal Waters. NorthHolland Publishing Company. Amsterdam

Elfidasari, 2012. Identifikasi Jenis Teripang Genus Holothuria Asal Perairan Sekitar Kepulauan Seribu Berdasarkan Perbedaan Morfologi. Jurnal Al-Azhar Indonesia Seri Sains dan Teknologi, Vol.1,No.3

Gasango, H., 2013 Struktur Komunitas Teripang (Holothuridea) di Pantai desa Kakara Pulau Kecamatan Tobelo Kabupaten Tobelo. Jurnal Ilmiah Platax. Vol,1:(4)

Hartati. R., Purwati P.,Widianingsih. 2009Timun Laut, (Teripang, Holothuroidea : Echinodermata) Di Indonesia: Biologi, Pengelolaan Dan Konservasinya. Navila Idea: Yogyakarta. $72 \mathrm{hlm}$.

Herman Kaenda, Ermayanti dan La Ode Alirman Afu. 2016. Hubungan Panjang Teripang Di Perairan Tanjung Tiram Konawe Selatan. Jurnal Manajemen Sumber Daya Perairan. 2:171-177.

Hyman, L.H., 1955. The Invertebrata Echinodermata, The Coelomate Bilateria. Vol.IV. Mc Graw Hill Book Co. New York. 224 P.

Kordi, M.G. 1997. Budidaya Kepiting dan Ikan Bandeng di Tambak Sistim Polikultur. Dahara Prize: Semarang.

Kordi, MGH. 2010. A to Z Budi Daya Biota Akuatik untuk Pangan, Kosmetik, dan Obat-Obatan.Yogyakarta : ANDI.

Lerman, M. 1986. Marine Biology Environment, Diversity and Ecology. The Benjamin/ Cumminngs Publishing Company, Inc. California.

Livingstone, I., 1995 Main Internal anatomical features of a cucumarid sea cucumber

Manan. A., 2011 Kepadatan Larva Ikan pada Kondisi Air Pasang dan Surut di Muara Sungai Pilang Sari, Desa Pidodo Kulon, Kendal Jurnal Fakultas Perikanan dan Kelautan. Universitas Airlangga, Surabaya.

Mansur, 2015. Struktur Komunitas Teripang (Holothuridea) Di Perairan Pulau Laut. Ilmu Kelautan. Him 6-12

Martoyo SM,J., Aji Nugroho. Winanto dan Tjahhyo. 2006. Budidaya Teripang.
Edisi Revisi Cetakan 6. Penebar Swadaya .75 hal.

Narayaman, A. S. 2014. Perilaku Pemijahan Teripang pasir (Holothuria scabra) Berdasarkan Faktor Lingkungan (suhu) di Desa Ohoi Letman Kecaamatan Kei Kecil Kabupaten Maluku Tenggara . Program Studi Pendidikan Bilologi. Jurnal Biopendix. 1 (1) 77-82.

Nontji, A. 2005. Laut Nusantara. Jambatan. Jakarta. hlm. 126.

Nybakken, 1992. Biologi Laut, Suatu Pendekatan Biologi. Gramedia. Jakarta.

Odum, 1993. Fundamental of Ecology. Gajah Mada University Press. Yogyakarta.

Panggabean, T.M. 1987. Membudidayakan Teripang/Ketimun Laut Dalam Rangka Meningkatkan Produksi Hasil Laut Di Indonesia. Ditjen Perikanan Berkerjasama Dengan Internasional Developed Research Central, INFIS Manual Seri 44.

Pariwono, J.I., 1989. Gaya Penggerak Pasang Surut. Dalam Pasang Surut. Penyunting Ongkosongo dan Suyarso. Puslitbang Oseanologi LIPI. Jakarta.

Purwati, P. 2005. Reproductive pattern on Holothuria scabra (Echinodermata :Holothuroidea) in Indonesian waters. (Inpress). Marine Research in Indonesia.

Pawson D. 1970. The Marine Fauna of New Zealand: Sea Cucumbers (Echinodermata:Holothuroidea). New Zealand Departmentof Science and Industry Research Bulletin, 201: 1-50.

Reseck, J.Jr., 1979. Marine Biology. Reston Publishing Company, Ina. Virginia

Romimohartato, K dan Junawa S.2007. Biologi Laut Ilmu Pengetahuan Tentang Biologi Laut. Djambatan. Jakarta. 540 Hal.

Rustam. 2002. Struktur Komunitas Teripang Berdasarkan Tipe Substrat di Lokasi

Intertidal Pada Perairan Pantai Desa Torokeku Kecamatan Tinanggea Kabupaten Kendari. Skripsi. UniversitasHalu Oleo Kendari.

Rajab, W.A. 1996. Teripang di Teluk Un, Pulau Dullah, Maluku Tenggara, Rec. p. 13-15 (Abstr)

Rohani, 1998. Sebaran Ukuran dan Kematangan Gonad Teripang Pasir Holothuria scabra pada berbagai 
kedalaman Perairan. Tesis Program Pasca Sarjana. IPB. Bogor.

Samad, M. Y. 2000. Perbaikan Kualitas Produk Industri Kecil Teripang. Jurnal Sains dan Teknologi Indonesia. Vol.3. Juni. P. 52-53.

Supriharyono, M. S. 2002. Pengelolaan Ekosistem Terumbu Karang, Jakarta: Djmbatan. him:24-25.

Sutaman.1993. Petunjuk Praktis Budidaya Teripang.Kanisius. Jakarta Purwati P, Wirawati I. 2009. Holothuridae (Echinodermata; Holothuroidea, Aspidochirotida) perairan dangkal Lombok Barat, Bagian I. Genus Holothuria. J Oseano, 2 (21): 1-25

Soegianto, A. 1994. Ekologi Kuantitatif. Usaha Nasional. Surabaya.

Thorpe, S.A. 2009. Elements Of Physical Oceanography. A Derivate Of Ocean Sciences, Second Edition. Elsevier. London. P 647.

Wati, T. K. 2013. Keanekaragaman Gastropoda di Padang Lamun Desa Pengudang Kabupaten Bintan. Skripsi. Universitas Maritim Raja Ali Haji, Tanjung Pinang.

Wibowo S, Yunizal, Setiabudi E, Erlina MD, Tazwir. 1997. Teknologi Penanganan dan Pengolahan Teripang (Holothrunidae). Jakarta. IPPL Sipil.

Yusron, E. 2009. Biodiversitas Fauna Ekhinodermata di Perairan Selat Lembeh, Situng. Sulawesi Utara. Oseanologi dan Limnologi di Indonesia. 35 (2) : $225-237$.

Yusron, E. 2010. Keanekaragaman Jenis Echinodermata di Perairan Teluk Kuta Nusa Tenggara Barat. Jurnal Makara Sains. 13 (1): 45-49.

Yusron, E., dan Susetion 2006 Struktur Komunitas Teripang (Holothuridea) di Perairan Tanjung Merah, Selat Lembeh Sulawesi Utara. Jurnal Perikanan (J.Fish.Sci) VIII (1):134-138

Yusron, E. dan Pitra W. 2004. Struktur Komunitas Teripang (Holothuroidea) Di Beberapa Perairan Pantai Kai Besar, Maluku Tenggara. Jurnal Sains. 8 (1):15-20 